$\mathrm{O} 44$

\title{
МЕТОДИЧНИЙ ІНСТРУМЕНТАРІЙ РАНЖУВАННЯ ЗАГРОЗ \\ В СИСТЕМІ УПРАВЛІННЯ ЕКОНОМІЧНОЮ БЕЗПЕКОЮ ПІДПРИЕМСТВ У ГЛОБАЛЬНОМУ ПРОСТОРІ
}

Нікітіна А. В., канд. екон. наук, доцент

Харківський національний автомобільно-дорожній університет

Шершенюк О. М., канд. екон. наук, доцент

Харківський національний автомобільно-дорожній університет

Постановка проблеми в загальному вигляді та їі зв'язок 3 важливими науковими або практичними завданнями. Сьогоденні реалії розбудови економіки України становлять досить неоднозначне підгрунтя для функціонування, становища підприємств та їх економічної безпеки, зокрема: 3 одного боку - наявність широкого кола проблем, які пов'язані із загостренням світової економічної кризи, нестабільністю у внутрішньополітичній, економічній, енергетичній в інших сферах, а з іншого - швидкі темпи розвитку й адаптації до змінюваного зовнішнього середовища, які носять позитивний i негативний характер. У такому контексті особливого гострими стають питання створення високоефективної системи економічної безпеки підприємства (ЕБП) та й управління останньою, яка направлена на захист суб'єктів господарювання від внутрішніх та зовнішніх загроз, деструктивних і дестабілізуючих явищ. Крім того, спектр загроз, з якими стикається кожне підприємство, є досить різноманітним, а перелік такої сукупності небезпечних явищ $€$ важливим елементом багатоетапної і складної процедури управління економічною безпекою, оскільки настання несприятливих, небезпечних подій може призвести до втрати будь-яких видів ресурсів, потенційних шансів під час здійснення діяльності суб'єкта господарювання. 
Середовище, у якому функціонує будь-яка виробнича система, являє собою сукупність динамічних, диференційованих і різноманітних чинників, які постійно впливають, змушують пристосовуватись до себе та здатні руйнувати у деяких випадках об’єкти. Плідна й ефективна діяльність підприємства повинна включати у себе не лише дослідження свого середовища й природи його змін, але й можливість адекватно реагувати на ці зміни, оскільки невдала або несвоєчасна реакція може спричинити до значні збитки або неефективне управлінське рішення може призвести до припинення діяльності підприємства взагалі.

Аналіз останніх досліджень і публікацій, в яких покладений початок вирішенню даної проблеми і на які спирається автор. Дослідженню сутності i причин виникнення загроз присвячено чимало наукових праць багатьох вчених, зокрема: В. Гапоненко, А. Баспелько, Т. Васильцива, А. Власкова, О. Груніна, В. Гусєва, С. Дубецької, О. Козаченко, В. Пономарьова, О. Ляшенко, Г. Мінаєва та інших.

Важливим та досить грунтовним вважаємо підхід Г. ПастернакТаранушенка, який вбачає під системою економічної безпеки взаємопов'язану сукупність всіх видів захисту національних інтересів, зокрема: політичного, військового, економічного, правового, інформаційного тощо [1].

Крім того, одним із найвищих щаблів у ієрархії системи економічної безпеки автори $[1,2]$ визначають економічну ж безпеку держави, яку інтерпретують як комплексну систему 3 великою кількістю відгалужень або напрямів, а саме: демографічний, екологічний, ресурсний, прісноводний, продовольчий, енергетичний, інформаційний та інші.

За конкурентним підходом, який запропоновано у науковому джерелі [3], визначення економічної категорії «економічна безпека підприємства» пропонується ідентифікувати головну мету забезпечення ЕБП як досягнення конкурентних переваг, зумовлених відповідністю матеріального, фінансового, кадрового, техніко-технологічного потенціалів і організаційної структури підприємства його стратегічним цілям і завданням, але сам факт наявності 
таких переваг потенціалу, без їх використання і відповідної реалізації не гарантує підприємству економічної безпеки.

Велика кількість деструктивних чинників зовнішнього середовища спричинила виникнення ще одного наукового підходу до економічної безпеки підприємства - захисного, прибічниками якого є Д. Ковальов, Т. Сухорукова, О. Козаченко, О. Ляшенко та інші $[6,7,8]$. Зовнішнє оточення та його вплив на підприємство є головним стрижнем досліджень вчених. Трактування економічної безпеки підприємства у працях Д. Ковальов і Т. Сухорукова [4, 5, 6, 7] є таким: сукупність факторів, що визначають забезпечення економічних інтересів, здатність протистояти загрозам, незалежність, платоспроможність, стійкість тощо. Разом з тим, незважаючи на детальне вивчення факторів середовища, науковці не враховували необхідність забезпечення сталого розвитку та необхідність урахування часового чинника, що й відносимо до головного недоліку цієї концепції.

Невирішені складові загальної проблеми. Хоча $є$ такі питання, які залишись поза увагою вчених, а саме: стосовно універсальності й однозначності наукової думки щодо розмежування небезпечних явищ, тому вважаємо доцільним і необхідним у контексті розкриття сутності ЕБП розглянути багатовекторність загроз та ідентифікувати значущість кожної.

Формулювання мети статті (постановка завдання). Головною метою написання статті є розробка методичного інструментарію ранжування загроз в системі управління економічною безпекою підприємств у глобальному просторі.

Викладення основного матеріалу дослідження 3 повним обгрунтуванням отриманих наукових результатів.

Під час процесу управління економічною безпекою підприємств важливим етапом стає ранжування всього спектру загроз, що проявляються у вигляді деструктивних впливів і дестабілізуючих явищ та здатні спричинити суттєві збитки, знизити значення результативних показників роботи автотранспортних підприємств (АТП). Оскільки, враховуючи мобільність i 
динамічність розвитку постійні зміни у параметрах оточення є суттєвим підгрунтям для здійснення основного виду діяльності, а саме: надання послуг.

3 метою підвищення ефективності управління економічною безпекою підприємств пропонується впровадження науково-методичних положень про ранжування домінуючих загроз (на прикладі АТП), які спрямовані на швидке i своєчасне виявлення небезпечних і дестабілізуючих явищ та дозволить знизити можливі втрати, котрі спричинені негативними змінами параметрів зовнішнього і внутрішнього середовища функціонування підприємства (рис. 1). Підкреслимо, що сукупність факторів впливу розглядається не як детальний перелік їі елементарних частин, а як структурована система взаємопов’язаних та взаємодоповнюючих елементів. Запропоновано підхід до визначення домінуючих загроз, що притаманні функціональним складовим економічної безпеки АТП, допоможе керівникам останніх швидко зорієнтуватися у сукупності чинників, що збільшують рівень нестабільності й порушують умови сталого розвитку.

Головним сутнісним змістом запропонованої моделі $є$ ідентифікація найбільш суттєвих загроз, що спричиняють негативних вплив на діяльність автотранспортних підприємств. Необхідність і подальші дослідження саме цієї площини управління економічної безпеки АТП обумовлена багатоаспектною діяльністю суб’єктів господарювання, що надають автотранспортні послуги, великим розмаїттям дестабілізуючих і деструктивних явищ, які загрожують ефективному функціонуванню АТП. При чому, важливо наголосити, на той факт, що з одного боку, чим більший є перелік сканованих загроз, тим більша вірогідність швидше запропонувати комплекс управлінських заходів щодо виявлення, локалізації або навіть ліквідації негативних ситуацій, які можуть спричинити кризовий стан на підприємстві. 


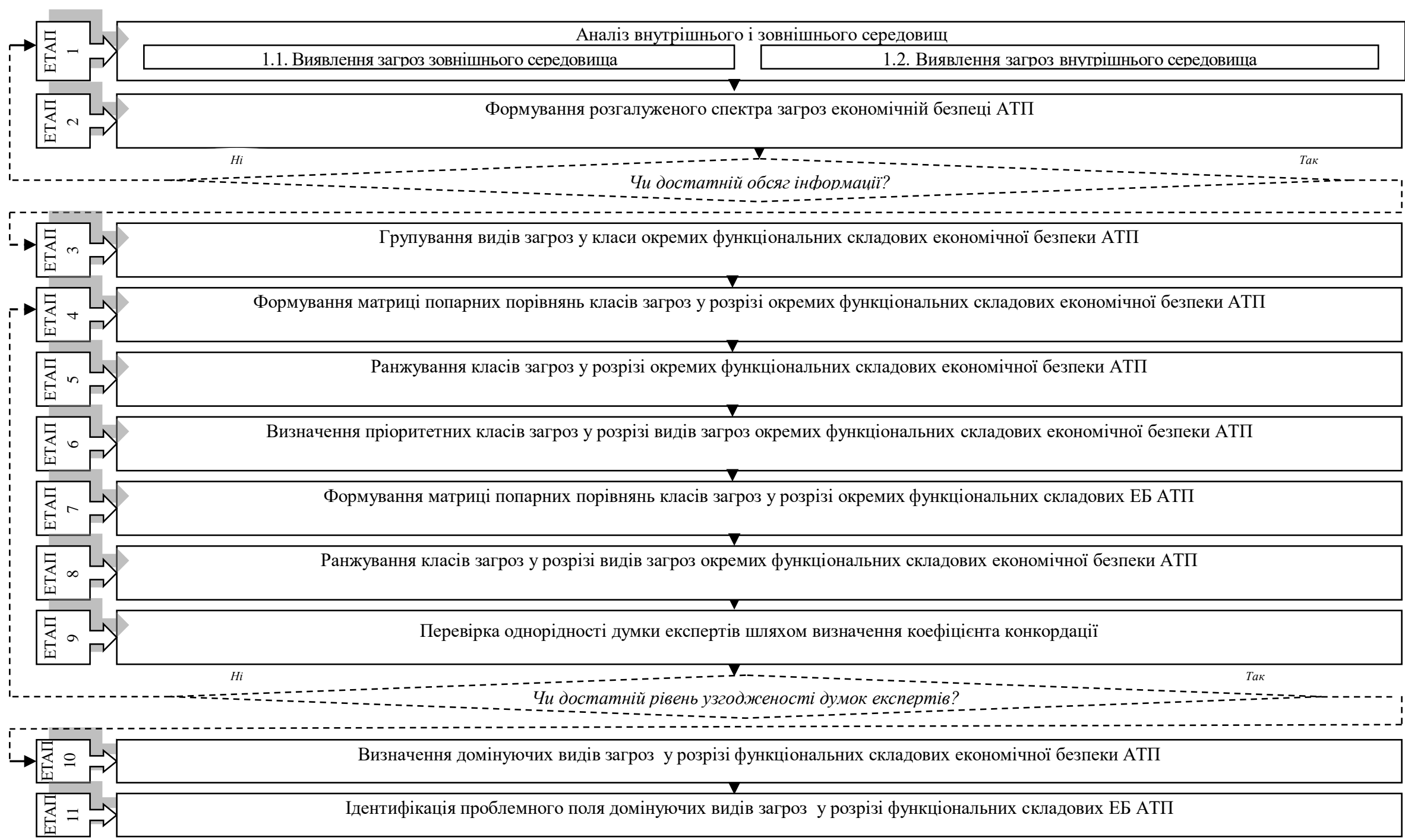

Рис. 1. Алгоритм ранжування домінуючих загроз в системі управління економічною безпекою підприємств (на прикладі АТП) [9] 
3 іншого боку, реалізація такої процедури $є$ досить складною i проблемною 3 огляду на те, що деякі показники, що визначають ступінь настання загрози, інформаційно не визначені, існують значні перепони щодо отримання такої інформації чи взагалі відсутня можливість відбору допустимих моделей поведінки підприємств. Тому, на наш погляд, доцільним $є$ виокремлення найбільш значущих і домінуючих загроз, що притаманні тій або іншій функціональній складовій економічної безпеки АТП.

На першому етапі процесу ідентифікації домінуючих загроз, що притаманні окремими складовим економічної безпеки АТП, здійснюється аналіз внутрішнього і зовнішнього середовищ функціонування підприємств, визначаються найбільш суттєві негативні чинники, що спричиняють суттєвий вплив на діяльність АТП. Потім йде процес формування розгалуженого спектру загроз економічній безпеці автотранспортного підприємства. На третьому етапі здійснюється декомпозиція задачі в ієрархію, формується матриця попарних порівнянь класів загроз, виокремлюються пріоритетні для автотранспортного підприємства класи загроз окремих функціональних складових ЕБП, а саме: загрози фінансовій, кадровій (інтелектуальній), техніко-технологічній, політико-правовій, інформаційній, екологічній, інноваційно-інвестиційній складовій економічної безпеки автотранспортного підприємства [10]. Далі йде виокремлення множини загроз, значущість яких необхідно визначити й оцінити.

На підгрунті отриманих результатів попарного порівняння класів загроз окремих функціональних складових між собою формується матриця, яка агрегує у собі думки експертів, які є компетентними i неупередженими фахівцями в певній галузі знань (працівників, які $\epsilon$ відповідальними у фінансових питаннях, технологічному процесі, інформаційному, інвестиційному й юридичному забезпеченні, екологічному нагляді) $[11,12]$.

Заключним шагом у процесі ранжування домінуючих загроз в системі управління економічною безпекою автотранспортних підприємств є синтез загроз, який включає у себе знаходження добутку локальних пріоритетів та 
пріоритетів відповідного класу загроз функціональних складових економічній безпеці автотранспортного підприємства на більш високому рівні та визначається сума цих добутків за кожним елементом, таким чином знаходиться вектор глобальних пріоритетів, який дозволить виокремити домінуючі для підприємства види загроз.

Висновки 3 даного дослідження і перспективи подальших розробок за даним напрямом. 3 метою підвищення ефективності управління економічною безпекою підприємств запропоновано удосконалений методичний підхід до ранжування домінуючих загроз, який спрямований на швидке і своєчасне виявлення небезпечних і дестабілізуючих явищ та дозволить знизити можливі втрати, котрі спричинені негативними змінами параметрів зовнішнього i внутрішнього середовища функціонування підприємства. Подальшим етапом дослідження повинно стати імплементація запропонованої моделі ранжування домінуючих загроз в системі управління економічною безпекою підприємств як важливого елементу побудови принципової схеми управління економічної безпеки суб'єктів господарюванням, в якій необхідним $є$ ідентифікація домінуючих загроз та розробка обгрунтованих заходів щодо подальшої їх впливу на діяльність підприємства у розрізі окремих функціональних складових економічної безпеки підприємства.

\section{Перелік посилань}

1. Пастернак-Таранущенко Г. А. Економічна безпека держави: проблеми та механізми їх розв'язання. Вісник НАН України. 1998. №11-12. С. 70-75.

2. Пекін А. Економічна безпека підприємств як економіко-правова категорія. Економіст. 2007. №8. С. 23-25.

3. Белокуров В. В. Структура функциональных составляющих экономической безопастности предприятия : сайт. URL: http://www.safetyfactor.ru (дата обращения : 14.11.2018). 
4. Королев М. И. Экономическая безопасность фирмы: теория, практика, выборстратегии : монография. Москва, 2011. 284 с.

5. Ковальов Д., Сухорукова Т. Економічна безпека підприємства. Економіка Украӥни. 1998. № 10. С. 48-52.

6. Козаченко А. В. Пономарев В. П., Ляшенко А. Н. Экономическая безопасность предприятия: сущность и механізм обеспечения: монография, Київ, 2003. 280 с.

7. Козаченко А. В., Ляшенко О. М. Декомпозиція управління економічною безпекою підприємства. Вісник Хмельнищького нащіонального університету. Серія: Економічні науки. 2009. № 4. С. 34-38.

8. Дубецька С. П. Економічна безпека підприємств України. Недержавна система безпеки підприємства як суб'єкт нащіональної безпеки України: Зб. матер. наук.-практ. конф. / под ред. I. І. Тимошенко. Київ, 2003. С. 146-171.

9. Нікітіна А. В., Горовий Д. А., Бабич Д. В. Управління економічною безпекою автотранспортних підприємств в глобальному середовищі : монографія. Харків, 2015. 280 с.

10. Бандурка О. М., Духов В. С., Петрова К. Я., Червяков І. М. Основи економічної безпеки. Харків, 2003. 236 с.

11. Кириченко О. А. Деякі критерії оцінки економічної безпеки підприємства. Інвестииіï: практика та досвід. 2008. № 23. С. 22-24.

\section{References}

1. Pasternak-Taranushchenko, G. A. (1998), Economic security of the state: problems and mechanisms for their solution [Ekonomichna bezpeka derzhavy: problemy ta mekhanizmy yikh rozviazannia]. Bulletin of the National Academy of Sciences of Ukraine, No. 11-12, P. 70-75.

2. Pekin, A. (2007), Economic security of enterprises as an economic-legal category [Ekonomichna bezpeka pidpryiemstv yak ekonomiko-pravova katehoriia], Economist, No. 8, P. 23-25. 
3. Belokurov, V. V. (2009), The structure of the functional components of the enterprise's economic security [Struktura funktsyonalnih hsostavliaiushchykh эkonomycheskoi bezopastnosty predpryiatyia], available at :http://www.safetyfactor.ru (last accessed 14.11.2018)

4. Korolev, M. I. (2011), Economic security of the firm: theory, practice, choice of strategy [Ekonomycheskaia bezopasnost fyrmi: teoryia, praktyka, vyborstratehyy], - Moscow, Economics, 284 p.

5. Kovalev, D., Sukhorukov, T. (1998), Economic security of the enterprise, Economy of Ukraine, No. 10, P. 48-52.

6. Kozachenko, A.V., Ponomarev, V. P., Lyashenko, A. N. (2003). Economic security of an enterprise: the essence and mechanism of provision [Dekompozytsiia upravlinnia ekonomichnoiu bezpekoiu pidpryiemstva], Kiev, 280 p.

7. Kozachenko, A. V., Lyashenko, O. M. (2009). [Decomposition of management of economic safety of the enterprise], Bulletin of the Khmelnitsky National University. Series: Economic Sciences, No. 4, P. 34-38.

8. Dubetskaya, S. P. (2003), Economic security of Ukrainian enterprises [Ekonomichna bezpeka pidpryiemstv Ukrainy], Kiev, View Europe, P. 146-171.

9. Nikitina, A. V., Gorovoy, D. A., Babich, D. V. (2015), Management of economic safety of motor transport enterprises in the global environment [Upravlinnia ekonomichnoiu bezpekoiu avtotransportnykh pidpryiemstv $v$ hlobalnomu seredovyshchi], Kharkiv, 280 p.

10. Bandurka, O. M., Dukhov, V. Ye., Petrova, K. Ya., Chervyakov, I. M. (2003), Fundamentals of Economic Security [Osnovy ekonomichnoi bezpeky], Kharkiv, $236 \mathrm{p}$.

11. Kirichenko, O. A. (2008). Some criteria for assessing the economic security of an enterprise [Deiaki kryterii otsinky ekonomichnoi bezpeky pidpryiemstva], Investments: practice and experience, No. 23, P. 22-24. 
Нікітіна Аліна Вадимівна - кандидат економічних наук, доцент, Харківський національний автомобільно-дорожній університет, доцент кафедри обліку, оподаткування та міжнародних економічних відносин, м. Харків, Україна; e-mail: n-a-v-1@urk.net; ORCIDID: https://orcid.org/0000-0001-74400240. Моб.0504061119

Никитина Алина Вадимовна - кандидат экономических наук, доцент, Харьковский национальный автомобильно-дорожный университет, доцент кафедры учета, налогообложения и международных экономических отношений, г. Харьков, Украина

Nikitina Alina - Candidate of Sciences (Economics), Associate Professor, Kharkiv National Automobile and Highway University, Associate Professor, Department of Accounting, Taxation and International Economic Relations, Kharkiv, Ukraine

Шершенюк Олена Миколаївна - кандидат економічних наук, доцент, Харківський національний автомобільно-дорожній університет, доцент кафедри економіки і підприємництва, м. Харків, Україна; е-mail: sheralyona@gmail.com; ORCIDID: https://orcid.org/0000-0002-9959-2725. Моб. 0501513009

Шершенюк Елена Николаевна - кандидат экономических наук, доцент, Харьковский национальный автомобильно-дорожный университет, доцент кафедры экономики и предпринимательства, г.Харьков, Украина

Shershenyuk Elena Nikolaevna - Candidate of Science (Economics), Associate Professor, Kharkiv National Automobile and Highway University, Associate Professor, Department of Economics and Entrepreneurship, Kharkiv, Ukraine 


\section{Нікітіна А.В., Шершенюк О.М. МЕТОДИЧНИЙ ІНСТРУМЕНТАРІЙ РАНЖУВАННЯ ЗАГРОЗ В СИСТЕМІ УПРАВЛІННЯ ЕКОНОМІЧНОЮ БЕЗПЕКОЮ ПІДПРИЕМСТВ У ГЛОБАЛЬНОМУ ПРОСТОРІ}

Меma - розробка методичного інструментарію ранжування загроз в системі управління економічною безпекою підприємств у глобальному просторі. Методика дослідження. Для досягнення поставленої мети у науковій роботі були використані такі загальнонаукові та спеціальні методи i прийоми дослідження: методи узагальнення та абстрагування - для дослідження категоріального базису економічної безпеки, теоретичних засад та інструментарію управління економічною безпекою підприємств; системного i комплексного підходу - для розробки науково-методичних рекомендацій щодо ранжування домінуючих загроз у системі забезпечення економічної безпеки автотранспортних підприємств; метод аналізу і синтезу - для виявлення загроз основних функціональних складових ЕБП. Результати досліджсення. У статті проаналізовано концепції до визначення сутності економічної безпеки підприємства. Визначено головні особливості та чинники управління економічною безпекою підприємства. Підкреслено, що середовище, у якому функціонує будь-яка виробнича система, являє собою сукупність динамічних, диференційованих i різноманітних чинників, які постійно впливають, змушують пристосовуватись до себе та здатні руйнувати у деяких випадках об'єкти. Обгрунтовано, що плідна й ефективна діяльність підприємства повинна включати у себе не лише дослідження свого середовища й природи його змін, але й можливість адекватно реагувати на ці зміни, оскільки невдала або несвоєчасна реакція може спричинити до значні збитки або неефективне управлінське рішення може призвести до припинення діяльності підприємства взагалі. 3 метою підвищення ефективності управління економічною безпекою підприємств запропоновано удосконалений методичний підхід до ранжування домінуючих загроз, який спрямований на швидке i своєчасне виявлення небезпечних і дестабілізуючих явищ та дозволить знизити можливі втрати, котрі спричинені негативними змінами параметрів зовнішнього i внутрішнього середовища функціонування підприємства. Головним сутнісним змістом запропонованої моделі є ідентифікація найбільш суттєвих загроз, що спричиняють негативних вплив на діяльність автотранспортних підприємств. Запропоновано підхід до визначення домінуючих загроз, що притаманні функціональним складовим економічної безпеки АТП, допоможе керівникам останніх швидко зорієнтуватися у сукупності чинників, що збільшують рівень нестабільності й порушують умови сталого розвитку. Подальшим етапом дослідження повинно стати імплементація запропонованої моделі ранжування домінуючих загроз в системі управління економічною безпекою підприємств як важливого елементу побудови принципової схеми управління економічної безпеки суб'єктів господарювання, в якій необхідним є ідентифікація домінуючих загроз та розробка обгрунтованих заходів щодо подальшої їх впливу на діяльність підприємства у розрізі окремих функціональних складових економічної безпеки підприємства. Наукова новизна розроблено науковометодичні положення про ранжування домінуючих загроз, які, на відміну від 
існуючих, детермінують значущість і ступінь впливу кожної загрози у розгалуженій сукупності дестабілізуючих явищ, що притаманні функціональним складовим економічної безпеки підприємств, та дозволяють знизити можливі втрати, які спричинені негативними змінами параметрів зовнішнього і внутрішнього середовища, що на відміну від існуючих, дає можливість визначення домінуючих загроз, що притаманні функціональним складовим економічної безпеки суб'єктів господарювання, та допоможе керівникам останніх швидко зорієнтуватися у сукупності чинників, що збільшують рівень нестабільності й порушують умови сталого розвитку. Практичне значення отриманих результатів полягає у тому, що одержані результати і запропоновані розробки становлять методичну базу ефективного управління економічною безпекою підприємства, сприяючи підвищенню обгрунтованості управлінських рішень у розгалуженій сукупності дестабілізуючих явищ.

Ключові слова: загроза; система; ранжування загроз; економічна безпека підприємства; управління економічною безпекою підприємства.

\section{Никитина А.В., Шершенюк О.М. МЕТОДИЧЕСКИЙ ИНСТРУМЕНТАРИЙ РАНЖИРОВАНИЯ УГРОЗВ СИСТЕМЕ УПРАВЛЕНИЯ ЭКОНОМИЧЕСКОЙ ПРЕДПРИЯТИЙ В ГЛОБАЛЬНОМ ПРОСТРАНСТВЕ}

Цель - разработка методического инструментария ранжирования угроз в системе управления экономической безопасностью предприятий в глобальном пространстве. Методика исследования. Для достижения поставленной цели в научной работе были использованы такие общенаучные и специальные методы и приемы исследования: методы обобщения и абстрагирования - для исследования категориального базиса экономической безопасности, теоретических основ и инструментария управления экономической безопасностью предприятий; системного и комплексного подхода - для разработки научно-методических рекомендаций по ранжирование доминирующих угроз в системе обеспечения экономической безопасности автотранспортных предприятий; метод анализа и синтеза - для выявления угроз основных функциональных составляющих безопасности предприятия. Результаты исследования. В статье проанализированы концепции к определению сущности экономической безопасности предприятия. Определены главные особенности и факторы управления экономической безопасностью предприятия. Подчеркнуто, что среда, в которой функционирует любая производственная система представляет собой совокупность динамических, дифференцированных и различных факторов, которые постоянно влияют, заставляют приспосабливаться к себе и способны разрушать в некоторых случаях объекты. Обосновано, что плодотворная и эффективная деятельность предприятия должна включать в себя не только исследование своей среды и природы его изменений, но и адекватно реагировать на эти изменения, поскольку неудачная или несвоевременная реакция может привести к значительные убытки или неэффективное управленческое решение может 
привести к прекращению деятельности предприятия вообще. С целью повышения эффективности управления экономической безопасностью предприятий предложен усовершенствованный методический подход к ранжирование доминирующих угроз, направленный на быстрое и своевременное выявление опасных и дестабилизирующих явлений и позволит снизить возможные потери, которые вызваны негативными изменениями параметров внешней и внутренней среды функционирования предприятия. Главным сущностным содержанием предложенной модели является идентификация наиболее существенных угроз, которые вызывают негативных влияние на деятельность автотранспортных предприятий. Предложен подход к определению доминирующих угроз, присущих функциональным составляющим экономической безопасности АТП, поможет руководителям последних быстро сориентироваться в совокупности факторов, увеличивающих уровень нестабильности и нарушают условия устойчивого развития. Следующим этапом исследования должно стать имплементация предложенной модели ранжирования доминирующих угроз в системе управления экономической безопасностью предприятий как важного элемента построения принципиальной схемы управления экономической безопасности субъектов господаювання, в которой необходимо идентификация доминирующих угроз и разработка обоснованных мер по дальнейшей их влияния на деятельность предприятия в разрезе отдельных функциональных составляющих экономической безопасности предприятия. Научная новизна: разработаны научно-методические положения о ранжирование доминирующих угроз, которые, в отличие от существующих, детерминируют значимость и степень влияния каждой угрозы в разветвленной совокупности дестабилизирующих явлений, присущих функциональным составляющим экономической безопасности предприятий, и позволяют снизить возможные потери, вызванные негативными изменениями параметров внешней и внутренней среды, в отличие от существующих, дает возможность определения доминирующих угроз, присущих функциональным составляющим экономической безопасности субъектов хозяйствования, и поможет руководителям последних быстро сориентироваться в совокупности факторов, увеличивающих уровень нестабильности и нарушают условия устойчивого развития. Практическая значимость заключается в том, что полученные результаты и предложенные разработки составляют методическую базу эффективного управления экономической безопасностью предприятия, способствуя повышению обоснованности управленческих решений в разветвленной совокупности дестабилизирующих явлений.

Ключевые слова: угроза; система; ранжирование угроз; экономическая безопасность предприятия; управления экономической безопасностью предприятия.

Nikitina A.V., Shershenyuk E.N. METHODOLOGY OF RANKING OF THREAT IN THE SYSTEM OF ENTERPRISES ECONOMIC SECURITY MANAGEMENT IN GLOBAL SPACE 
The purpose of tha article is to develop a methodological tool for ranking threats in the system of the enterprises economic security management in the global space. Methodology of research. To achieve this goal in scientific work the following general scientific and special methods and techniques of research were used: methods of generalization and abstraction - for studying the categorical basis of economic security, theoretical principles and tools for managing the economic security of enterprises; systematic and integrated approach - for the development of scientific and methodological recommendations on the ranking of the prevailing threats in the system of ensuring the economic safety of motor transport enterprises; the method of analysis and synthesis - to identify the threats of the main functional components of the EES. Findings. The article analyzes the concepts to determine the essence of enterprise economic security (EES). The main features and factors of the enterprise economic safety management are determined. It is emphasized that the environment in which any production system operates is a set of dynamic, differentiated and varied factors that constantly influence, make adaptation to oneself and are capable of destroying objects in some cases. It is substantiated that enterprise fruitful and effective activity should include not only research of its environment and the nature of its changes, but also the opportunity to respond adequately to these changes, as unsuccessful or untimely reaction can lead to significant losses or ineffective management decisions can lead to the termination of activity enterprises in general. In order to increase the efficiency of enterprises economic security management, the improved methodological approach to ranking of the dominant threats is proposed, which is aimed at quick and timely detection of dangerous and destabilizing phenomena and will allow to reduce possible losses caused by negative changes in the parameters of the external and internal environment of the company's operation. The main content of the proposed model is the identification of the most significant threats, which have a negative impact on the activity of motor transport enterprises. The approach to the definition of the dominant threats inherent in the functional components of the economic security of the APP is proposed to help the leaders of the latter quickly orient themselves in a combination of factors that increase the level of instability and violate conditions of sustainable development. The next stage of the study should be the implementation of the proposed model of ranking of the dominant threats in the system of managing the economic security of enterprises as an important element in the construction of a basic scheme for managing the economic security of housing enterprises, in which identification of the dominant threats is necessary and the development of reasonable measures for their further impact on the activity of the enterprise. sections of individual functional components of the economic security of the enterprise. Originality has developed scientific and methodological provisions on the ranking of the dominant threats, which, in contrast to the existing ones, determine the significance and degree of influence of each threat in an extensive set of destabilizing phenomena inherent in the functional components of the economic security of enterprises and allow to reduce possible losses caused negative changes in the parameters of the external and internal environment, which, in contrast to the existing, makes it possible to identify the dominant threats inherent in the functional components of the econs and will help the 
leaders of the latter quickly to orient themselves in the aggregate of factors that increase the level of instability and violate conditions of sustainable development. Practical value of the results obtained is that the obtained results and proposed developments constitute the methodological basis for effective management of the enterprise's economic security, contributing to the increase of the validity of managerial decisions in an extensive set of destabilizing phenomena.

Key words: threat; system; ranking of threats; economic security of the enterprise; management of economic safety of the enterprise. 